\section{OOPEN ACCESS}

International Journal of Applied Research in Social Sciences

P-ISSN: 2706-9176, E-ISSN: 2706-9184

Volume 3, Issue 2, P.No. 12-25, June, 2021

DOI: $10.51594 /$ ijarss.v3i2.225

Fair East Publishers

Journal Homepage: $\underline{\text { www.fepbl.com/index.php/ijarss }}$

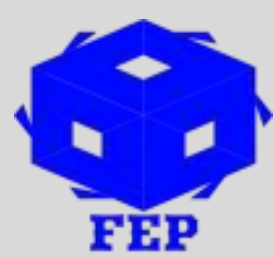

\title{
CHALLENGES IN COMBATING CHILD LABOUR IN SMALL-SCALE GOLD MINING COMMUNITIES IN SHINYANGA REGION, TANZANIA
}

\author{
Martin K. Malima ${ }^{1}$ \\ ${ }^{1} \mathrm{PhD}$ candidate, Institute of Development Studies, University of Dar es Salaam \\ P. O. Box 35091, Dar es Salaam, Tanzania
}

*Corresponding Author: Martin K. Malima

Corresponding Author Email: martinmalima80@gmail.com

Article Received: 16-05-21

Accepted: $30-05-21$

Published: 09-06-21

Licensing Details: Author retains the right of this article. The article is distributed under the terms of the Creative Commons Attribution-Non Commercial 4.0 License

(http://www.creativecommons.org/licences/by-nc/4.0/) which permits non-commercial use, reproduction and distribution of the work without further permission provided the original work is attributed as specified on the Journal open access page.

\begin{abstract}
Combating child labour in Tanzania is a challenging endeavour especially in small-scale gold mining communities. Studies on child labour in Tanzania indicate that the government in partnership with international actors has undertaken several intervention actions to control and eliminate child labour in the country. Yet, child labour continues to be dominant in virtually all economic sectors including small-scale gold mining for reasons not sufficiently known. This research sets out to explore the challenges that face anti-child labour actors in their efforts to control and reduce child labour in Kahama district in Shinyanga region. The study uses a qualitative methodology in order to gain an in-depth insight of the context, cultural realities, community members' views and experiences relating to child labour in small-scale gold mining communities. A sample size of 38 participants was drawn from among regional and district government officials, non-governmental organization (NGO) workers and community-based organization (CBO) activists responsible for combating child labour, small-scale gold miners, parents and children in Shinyanga region. Data was collected through in-depth interviews, focus group discussions and documents review. Findings revealed seven challenges facing anti-child labour actors in their efforts to combat child labour in small-scale gold mining communities all arising from within the household, local community and government contexts. The study recommends that the government, policy makers and other stakeholders should develop policy
\end{abstract}


interventions that effectively address these challenges in order to eradicate child labour in smallscale gold mining communities in the country.

Keywords: Child Labour, Small-Scale Gold Mining, Anti-Child Labour Actors, Challenges.

\section{INTRODUCTION}

Shinyanga region plays an important role in gold production in Tanzania. The first gold deposits were discovered in 1975 at Bulyanhulu in Kahama district by a herdsman who observed gold bearing quartz in the roots of a fallen tree and over the next two decades there was extensive movement into the area by around 30,000 artisanal miners who worked the ground at Bulyanhulu (Henkel et al., 2016). Until now small-scale gold mining is one of sources of nonfarm income generating activities for many community members in Kahama district. Smallscale gold mining activities are taking places at such areas as Segese, Lunguya, Bugarama, Isaka, Kahama urban, and Chela wards among others (Kalwani \& Fumbuka, 2014). Small-scale gold mining is essentially an economic activity that takes place in the informal sector which is characterized by easy entry into and exit from the mining industry (Becker, 2004).

However, many small-scale gold mining undertakings are known for being more labour intensive and for using children as one of the sources of cheap labour force (ILO, 2016; Metta, Ramadhan \& Geubbels, 2017; O'Driscoll, 2017). The child workers usually are engaged in all kinds of mining activities including digging, cleaning, shovelling, picking and transporting minerals, pounding ores with hammers, processing the mineral ore with mercury, looking for gold in tailings, bringing food and firewood to other workers and working in small business activities available in the mining areas (Bento, 2017; Merket, 2018; Mutagwaba et al., 2018). But involvement of children in gold mining activities falls under the internationally recognised worst form of child labour which is highly prohibited by international, national and local antichild labour actors and is targeted for elimination.

Literature on child labour elimination in Tanzania shows that the government in partnership with international and local anti-child labour actors has made considerable efforts to end worst forms of child labour in the country although the outcome shows a gradual declining incidence of child labour (Baregu, 2011; Brandt, Rutasitara, Selejio \& Trifkovic, 2017). The decline in child labour depict Tanzania's focused attention on five key intervention actions namely the established legal framework on child labour; institutional mechanisms for enforcement of laws and regulations, mechanisms to coordinate government efforts on child labour, policies on the worst forms of child labour and social programs and projects to address worst forms of child labour (Human Rights Watch, 2013; USDOL, 2018).

In general, combating child labour in small-scale gold mines in Tanzania like in other places in the world is challenging (O'Driscoll, 2017, ILO, 2019). For example, despite Tanzanian government's adoption of laws on child labour in hazardous work and conducting child labour inspections on licensed small-scale gold mines, these initiatives continue to be underfunded, not prioritized, and do not address unlicensed artisanal and small-scale gold miners. In addition, there are several other challenges that face the intervention actions undertaken to curtail child labour in small-scale gold mines. For example, failure of key government institutions and key officials to carry out their responsibilities and a number of government actors tasked with 
monitoring and withdrawing children from hazardous labour taking limited action to enforce the laws and policies at national, regional, district and village levels (USDOL, 2018).

Specifically, the challenges facing anti-child labour actors in their efforts to control and reduce child labour in Kahama district are not sufficiently known because the use of children's labour force continues until to date despite government and other anti-child labour actors' efforts to stop it. It is on this context, this research is conducted in order to explore and identify them so that appropriate intervention actions can be designed and implemented to address the problem of child labour in small-scale gold mining communities.

\section{LITERATURE REVIEW}

Baregu (2011) conducted a situational analysis on child labour in Tanzania mainland and Zanzibar. The results show that besides adopting and ratifying the International Labour Organisation's conventions on child labour namely the Minimum Age Convention No. 138 (1973); the Worst Forms of Child Labour Convention No. 182 (1999) as well as the United Nations Convention on the Rights of the Child (CRC), 1989; Tanzania established and implements several laws and regulations related to child labour. All together they form Tanzania's legal standard on child labour elimination. The problem in combating child labour remains in weak enforcement mechanisms.

Human Rights Watch (2013) examined on child labour and mercury exposure in Tanzania's small-scale gold mines. The results show that combating child labour in small-scale gold mines is a challenge. Efforts to combat child labour countinue to face shortage of workers and means for conducting regular visits and inspections of small-scale gold mines, lack of understanding and capacity to enforce child labour laws and regulations, and lack of resources and facilities necessary for controlling child labour.

O'Driscoll (2017) also carried out an overview of child labour in the artisanal and small-scale mining sector in Asia and Africa. The results show that mining accounts for $18.7 \%$ of the cases of children in hazardous work, working under exposure to health hazards. In response to this context, the Tanzanian government has adopted laws on child labour in hazardous work and conducts child labour inspections on licensed, small-scale mines. But, these initiatives are underfunded, not prioritised, and do not address unlicensed artisanal and small-scale gold miners. Similarly, although the National Education Act and the 2002-2006 Education Development Plan have secured children's rights to a free and compulsory primary education, yet children continue to pay a range of illegal contributions and many other school-related expenses. These expenses cause children to seek additional income from the small-scale gold mines and can contribute to their dropping out of school.

Metta, Ramadhani \& Geubbels (2017) carried out a formative assessment on pathways and experiences of children and adolescents who engage in artisanal and small-scale gold mining related activities in Tanzania. They found that children and women are the most employed workforce in informal artisanal and small-scale gold mining communities. Several child labour elimination policies and programmes have been implemented, yet it seems there are some cultural and societal factors perpetuating child mining making it dominant and difficult to control and reduce.

The inter-agency research programme, Understanding Children's Work (UCW) (2017) studied on Child labour and the youth decent work deficit in Tanzania. The results showed that 4.2 million children remain trapped in child labour including mining and quarrying. The challenges 
in combating child labour include lack of sufficient human resources and logistic support, lack of protection to children living in difficult circumstances who cannot fend for themselves, inadequate implementation of the relevant policies related to child protection, weak enforcement of existing labour laws and socio-cultural practices.

The International Labour Organization [ILO] (2018) examined related issues of child labour and youth employment in the context of Tanzania. The results show that Tanzania's strength in addressing child labour is based on her established legal framework, infrastructure, institutional mechanisms and social programmes although there have been some minimal positive progress achieved in controlling and monitoring child labour especially during the period from 2006 to 2014 whereby child labour incidence fell by only one percentage point among the children aged 5-17 years. In 2017, Tanzania also made minimal advancement in eliminating the worst forms of child labour. Still some policy gaps exist that hinder efforts to address child labour including mainstreaming child labour issues into other relevant policies. As a result, child labour continues to persist especially in small-scale gold mining communities.

\section{OBJECTIVE/SIGNIFICANCE OF THE STUDY}

\section{Objective of Study}

To explore the challenges facing anti-child labour actors in their efforts to control and reduce child labour.

\section{Significance of Study}

This study contributes to the understanding of the underlying forces that limit child labour elimination in small-scale gold mining undertakings. This understanding will enable key stakeholders, including international agencies, the government and policy makers to establish effective and sustainable parent-child centred policy interventions in order to achieve long lasting solutions to the problem.

\section{METHODOLOGY}

The study used a qualitative research approach which involved collection of qualitative data to best gain an in-depth understanding of participants' knowledge, perceptions, and lived experiences on the challenges facing anti-child labour actors responsible for child labour elimination in small-scale gold mines.

\section{Research Design}

The study used an explanatory and analytical design as it is useful in providing answers to questions requiring explanations and analysis to the presumed causal links in real-life interventions that are too complex for the survey or experimental strategies. There were various aspects under investigation that required explanations and analysis.

\section{Study Area}

The study took place in Kahama district in Shinyanga region where until to date small-scale gold mining activities are taking place. Kahama district is one among five districts of Shinyanga region located in north-western Tanzania. It is a very unique district since it is divided into three different district councils namely Ushetu, Kahama urban and Msalala. It is bordered to the north and west by Geita region, to the south by Tabora region and to the east by Shinyanga rural. It lies between latitudes $3^{0} 15$ and $4^{0} 30$ south of Equator and longitudes $31^{\circ}$ and $33^{\circ}$ east of Greenwich and covers an area of 8,477 square kilometers (Kalwani and Fumbuka, 2014). 
According to 2012 population census Kahama district had 523,802 persons (equivalent to 34.1 per cent of the regional population). This study covered Kahama urban district council only based on two key reasons. First, its geographic location and easier accessibility and second the presence of two large artisanal and small-scale gold mining sites namely Mwime located at Ilindi village in Zongomera ward and another one located at Bumbiti village in Mondo ward (figure 1).

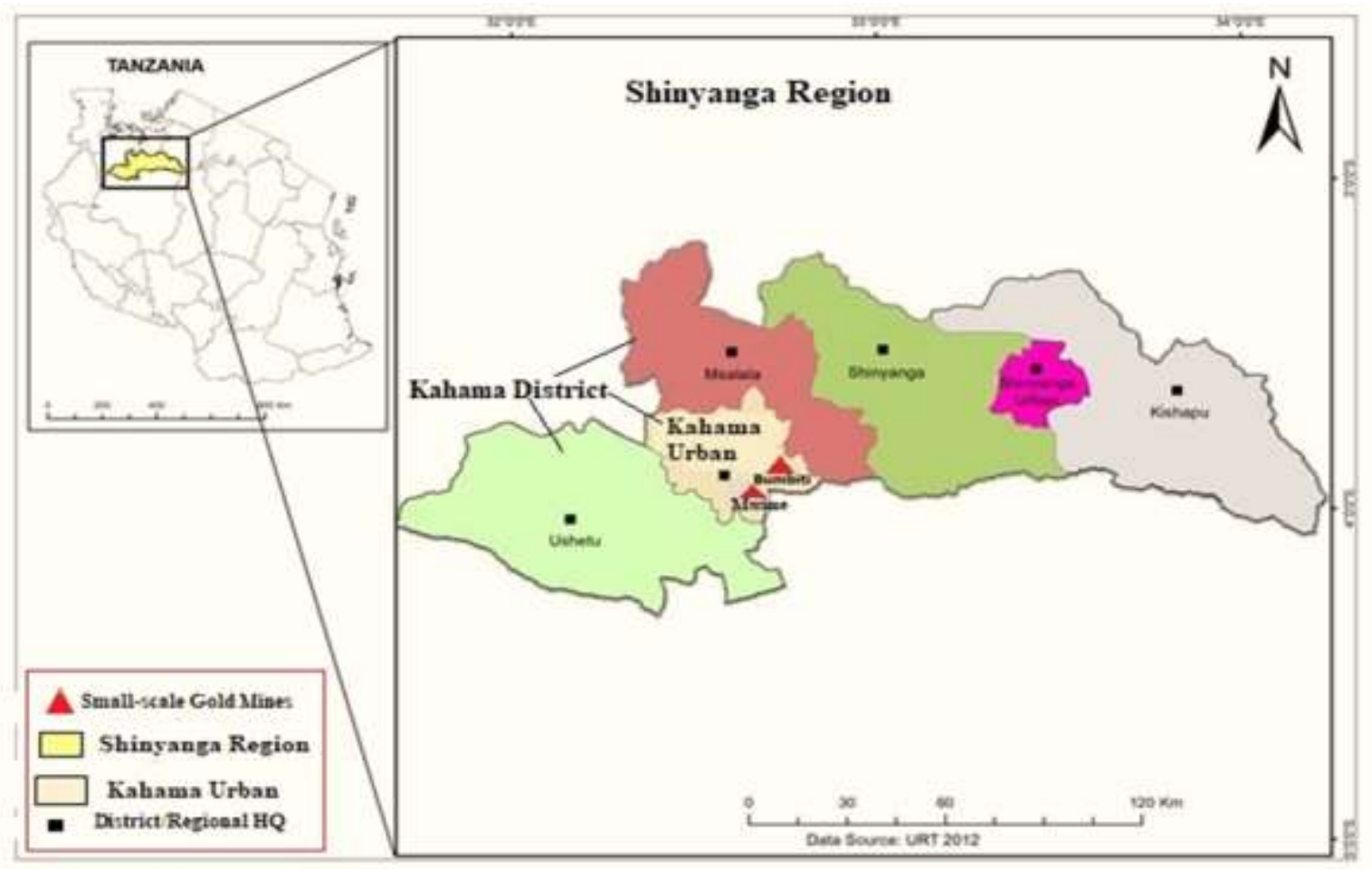

Figure 1. Location of Study Area in Kahama District in Shinyanga Region, Tanzania

Source: Modified from 2012 Population and Housing Census Basic Demographic and Socio-

Economic Profile of Shinyanga, (URT/NBS, 2016)

\section{Population of Study}

The population of study was composed of adult anti-child labour actors involved in the control, monitoring and combating child labour in Shinyanga region. Also it involved small-scale gold miners and children engaged in small-scale gold mining activities in the region. Adult participants were the targeted population because of having specific roles and responsibilities in monitoring, controlling and combating child labour in the areas of their jurisdiction. They were mainly those adult individuals who possess personal skills, specific positions within the society, or have the knowledge and experience on the issue of child labour and are capable of providing comprehensive information on child labour in small-scale gold mining communities as well as children who have been or are working in small-scale gold mines.

\section{Sampling Procedures}

Two purposive sampling methods were used to obtain 38 research participants. First, government and local community actors were purposively selected from a pool of regional and district labour officers, mining officers, social welfare officers, child labour inspectors, village leaders, child labour committee members, non-government organizations (NGOs), community based organizations (CBOs) and small scale gold miners. The selection criteria was based on their knowledge regarding child labour, role in the community or organization, their willingness to participate in the study, communicability, those having unbiased perspective and ability to 
provide detailed information of what is going on around them. Second, a snowball sampling was used to select the children participants.

\section{Data Collection and Analysis}

Primary data was collected through face to face in-depth interviews and focus group discussions, coded and thematically analysed. The analysis process involved first reviewing the data in order to remove any duplicate entities arising from the double recording of same points. This was followed by transcribing textual data mainly in the form of handwritten field notes. The transcripts were then developed and organized on a Microsoft excel based on the research objective and the responses from each participant. Each individual cell on a spread sheet was reviewed and assigned to a thematic area to which a cell colour code was applied. This datadriven inductive approach ultimately led to the identification of several emerging thematic areas each labelled with a different colour. If some points or responses fell under two themes, the response/worksheet cell was duplicated and each cell colour coded appropriately to ensure everything was recorded.

\section{RESULTS AND DISCUSSION}

The analysis of findings gathered from study participants revealed some unique inherent factors within households; local community and government that impose some challenges to anti-child labour actors responsible for tackling child labour in small-scale gold mining communities. There are about seven challenges most of them emanating from the local community and household supply side's contexts in which children are born, brought up and prepared for adulthood life and some from the government. The challenges are hereunder presented and discussed.

\section{Collective Pride}

Children constitute the largest group of individuals present in almost all communities in Tanzania. The national census of 2012 indicates the fact that the total population of people in Kahama district shows that children constituted nearly half of the total population (URT/NBS, 2016). For instance, there were 118, 323 (48.9\%) children out of a total population of 242,208 in Kahama urban district council. So, this depicts the image that children form a larger population of individuals in the district.

Analysis of findings gathered from study participants revealed that collective pride is an important challenge facing anti-child labour actors in their efforts to control and reduce child labour in small-scale gold mines. Collective pride is defined as emotional feelings that occur in groups which can be felt by most members of groups which a group is identified and how members conceive themselves and how they display group interests, values and aims (Sullivan, 2013). Collective pride occurs if people organize themselves in ways that generate high levels of spontaneous positive expression (i.e. an intense collective pride rather than a quiet satisfaction or appreciation) when they are together and close to the objects of their admiration (Reysen and Branscombe, 2008). Literature on collective pride provide insight of cases in which collectives are organised in different ways that allow for specific forms of emotional representation; that is, consideration of organisations that define emotions such as collective pride (Huebner, 2011).

Participants noted that there is higher recognition by local community members of the value of contribution that children make to economic and social well-being of their families. The positive recognition by community members play a big role in reinforcing collective pride among child 
workers especially by viewing their contributions to their families as an object of pride and admiration. This reflect the existence of a collective pride in terms of a positive social identity and feeling ascribed to child workers upon engaging into small-scale gold mining and earning money at such a tender age for their families. Participants also showed that there is even a widespread feeling among children themselves that they are doing something good to the family when they engage into income generating activities in small-scale gold mining and bring some income home.

During focus group discussions with NGO officials, it was also unanimously established that many community members and children have developed a collective pride - a positive social identity and feeling for being able to make some financial gain for their families at such a tender age. Participants also noted that children who work in small- scale gold mines to earn income for themselves and their families are viewed by local community members as 'prudent children.' Thus, collective pride ascribed to child workers motivate even many other children to engage in small-scale gold mining activities which increases the number of children being attracted into the labour market contrary to efforts to control and reduce child labour. There seems to be some pride when children help to provide for the family (ILO-IPEC, 2004). Therefore, the feeling of collective pride among households, children and community members as a whole tends to perpetuate child labour and turns out to be a challenge to anti-child labour actors in their efforts to control and reduce child labour in small-scale gold mines.

\section{Child-Headed Households}

Findings from interviews and focus group discussions with study participants also revealed that existence of a higher number of child-headed households was ranked higher as a challenge to anti-child labour actors in their efforts to control and reduce child labour in small-scale gold mines. They affirmed on the prevalence of child-headed households in the study area and showed that vulnerable children particularly older orphaned children usually take over the responsibilities of their diseased parents including engaging in various kinds of income generating activities like small-scale gold mining as a means of survival.

Statistics from the 2012 national census indicate that Kahama district had a population of 295,212 children aged $0-17$ years whereby 6.5 per cent were orphaned children who had lost one or both parents. Literature survey also indicate that child-headed households have emerged in the district due to many reasons including livelihood crisis affecting the families such as loss of one or both parents due to pandemic diseases like HIV/AIDS, or parental incapacitation, parental separation and abandoned children. (Dachi and Garrett, 2002; UNICEF, 2005; Härkönen., Bernardi., and Boertien, 2017). At the same time, the traditional system for providing protection through the extended family which has been playing a greater role in protecting orphans and needy children is no longer able to do so when the vast number of orphans is involved. Children who become household heads are vulnerable to all kinds of survival means including joining the labour market at an earlier age.

There are several other studies also providing an insight of child-headed households in the country. For example, a study by Andvig (2000) had earlier showed that children living in childheaded households especially after loosing their parents have got to take responsibility for their own survival and thus, become child labourers. An assessment report of the alternative care system for children in Tanzania by SOS Children's Villages International (2014) indicate the prevalence of child-headed households in the country most of which do not attend school, are 
sometimes engaged in household chores and housekeeping or engaged in various income generating businesses. The report further indicates that the trend of children living in childheaded households has been increasing which further suggests that the number of vulnerable children will continue to increase. Child-headed households do not always receive any support from either close members of the extended family or other community members and village leaders. Thus, the increasing number of child-headed households tends to foster increasing child labourers and become another challenge as it acts in an opposite direction against anti-child labour actors' efforts to control and prevent child labour especially in small-scale gold mining communities.

\section{Empowerment of Local Community Actors}

Findings from interviews and focus group discussions with study participants indicate that antichild labour actors at local community level are inadequately empowered by the government in their efforts to combat child labour in small-scale gold mines. A community refers to a structure of relationships through which a localized population provides its daily requirements (Diaz, 2000). In this study anti-child labour actors at community level consist of leaders at village and ward levels within the local governance system of Tanzania (Mollel, 2010). The anti-child labour actors at the village and ward levels include village and ward executive officers, ward counsellors, village chairpersons, village child labour committee members, and most vulnerable children committee members. These are the people who can participate in all campaigns targeted at the control and reduction of child labour.

Child labour cannot be eliminated without community members' participation in the process. Participation occurs if the community organizes itself and takes responsibility for managing the problem (Zadeh and Ahmad, 2010). In order for the community to take responsibility it requires their involvement in identifying the problem of child labour, developing actions to stop it, putting the actions into place and following them through (Cheetham, 2002). Several studies on community participation in solving problems emphasise on community participation since it is a means of ensuring local people's cooperation/collaboration with externally introduced programmes or processes to facilitate the effective implementation of such initiatives and achieve a set of objectives (Zadeh and Ahmed, 2010). Community participation empowers people to take responsibility for their development or in solving community problem through their acquisition of skills, knowledge and experience (Zadeh and Ahmed, 2010).

In this study, participants also observed that at the local community level, anti-child labour actors' empowerment and active participation in all activities and campaigns for monitoring and reducing child labour in small-scale gold mining communities are very essential as they enable them carry out their duties effectively and efficiently. Page and Czuba (1999) defines empowerment as a multidimensional social process that helps people gain control over their own lives. This is a process that fosters power in people, for use in their own lives, their communities and their society, by being able to act on issues that they define as important. According to Rowlands (1997) empowerment at different levels in the community is very essential. At personal level empowerment involves a sense of self-confidence and capacity and at relational level empowerment implies ability to negotiate and influence relationships and collective decisions. This suggests that, adequate empowerment of key participants in any community issues is very significant in addressing issues pertaining to that community. Therefore, any intervention to stop child labour in small-scale gold mining communities ought 
to involve households, local community leaders, child labour committee members, most vulnerable children committee members and any other anti-child labour actors. This can be carried out through sharing information on child labour, planning and acting together, and finally enabling the local community members to take total control and direct the process of child labour elimination. This form of empowerment would lead to a more active participation (more empowering) of the local community actors in child labour control and reduction campaigns. Hence, lack or inadequate empowerment of the local community actors in smallscale gold mining communities limits the collective vigour in the process of monitoring and preventing child labour. It opens the loop hole for easier entry of child workers into the smallscale gold mining labour market and becomes a challenge to local community anti-child labour actors responsible for combating child labour.

\section{Child Trafficking Agents}

Interviews conducted with study participants also revealed that the issue of child trafficking from one village, district and region carried out by some child trafficking agents present within the community was another common challenge to anti-child labour actors in their efforts to combat child labour. Through the child trafficking agents children are procured and supplied to small-scale gold miners to be employed in different gold mining activities and sites. This practice has been increasing the number of child workers in small-scale gold mines instead of controlling or reducing it. Participants also noted that, children who are trafficked to new destinations not only become vulnerable to all forms of child labour and abuse, but also encounter psychological distress due to separation from their parents, involvement in illicit business such as drug and alcohol abuse, prostitution and crime (ILO and UCW, 2010).

Literature shows that ILO Convention No. 138 (Article 3) prohibits people engaging children in all worst forms of child labour including sending children into slavery or practices similar to that such as trafficking of children (ILO and UCW, 2010). People who are engaged in procuring and trafficking of children from one village, district and region to places where small-scale gold mining activities are taking place, are not only fundamentally breaching that law but are committing an illegal practice. The AMCA Inter-consult Ltd (2012) asserts that normally those children lured by the child workers suppliers are often assumed to be rational and economically motivated and reaches the decision to move away from their homes after weighing the livelihood hardships experienced in the source area against the perceived comparative advantages in destination areas. Similarly, children are procured by trafficking agents and required to leave their homes and go away from their homes to work in small-scale gold mining sites because of the prospects or promises of becoming rich after digging and getting the mineral. Therefore, continuous supply of migrant child workers by trafficking agents is but another challenge to anti-child labour actors in their efforts to monitor and prevent child labour.

\section{Small-Scale Gold Miners' Mobility}

Findings from interviews and focus group discussions with study participants identified smallscale gold miners' high mobility as a significant challenge to anti-child labour actors in their efforts to monitor and prevent child labour in small-scale gold mining sites. One of the behavioural characteristics of small-scale gold miners is mobility which Lahiri-Dutt (2018) calls 'the gold rush fever' that grip many people in the mineral rich regions. Many small-scale gold miners in the study area and elsewhere do not settle on one area for long time but keep on moving from one gold rush site to another especially when they hear that a gold mine 
somewhere else is highly producing gold. ILO and UCW (2010) assert that, migration is a 'developing countries' issue. Small-scale gold miners constantly move between mining and processing sites and from one establishment to another.

Study participants also pointed out that the labour market in small-scale gold mining sites is basically unregulated, competitive and allows for free self-employment and a significant labour mobility open to even children based on their relative productivity potential. Small-scale gold mining is essentially an economic activity that takes place in the informal sector which is characterized by easy entry into and exit from the mining industry (Becker, 2004). Lahiri-Dutt (2018) also acknowledges the fact that artisanal and small-scale mining is often a seasonal activity and sometimes a resilience strategy against downturns in agricultural productivity due to natural or anthropogenic effects.

Therefore, small-scale gold miners' mobility is a problem to anti-child labour actors at local authorities as it becomes difficult to keep track of such incoming or outgoing migrants. This labour mobility freedom limits the process of child labour elimination as it becomes hard to design and implement the plan when the small-scale gold miners do not settle for a long time on one area. Hence, mobility of small-scale gold miners stands out to be a challenge to antichild labour actors in their efforts to control and reduce child labour because migrant smallscale gold miners do not each time establish permanent settlements on one mining site.

\section{Geographical Location}

Geographical location can be influenced by elements such as physical distance, topography, hydrology, climate and natural hazards. Any obstructions or prevailing adverse conditions these elements face limit movements of people, goods and information which have always been fundamental components of human society (Rodrigue, Comtois, and Slack, 2006). Obstructed physical distance limit interaction; topography always shape transportation but may be constrained by either slopes, valleys or plains; hydrological conditions like presence of tidal conditions of rivers and estuaries influence access; climate like rainy and dry seasons also influence accessibility, and natural hazards like floods due to heavy rainfalls play the same limiting role.

Results from interviews with study participants further revealed that geographical location of some small-scale gold mining sites is another important challenge to anti-child labour actors in their efforts to monitor and prevent child labour in small-scale gold mines. The study noted that most of the small-scale gold mines are located in remote areas except a few which are found in Kahama urban district council. The information gathered during focus group discussions with participants from Kahama urban district council underlined the fact that lack of finances and other facilities like means of transport to enable mining inspectors visit remote areas constrain the efforts to monitor and prevent child labour in small-scale gold mines. They pointed out that some small-scale gold mining sites are located in remote areas that are hard to reach using vehicles. So, in order for anti-child labour actors to reach there they need to hire motorbikes which are available at a higher cost which again is not always manageable with limited finances. Moreover, during rainy season it becomes even worse because many remote areas cannot be reached due to broken transport infrastructures. Therefore, where resources and facilities necessary for anti-child labour actors are scarce, it turns out to be very hard to visit those smallscale gold mines located in very remote areas and hence the whole exercise of child labour inspection and control is hindered. In general, the presence of obstructed elements that affect 
the geography of a given area particularly the geographic location of a small-scale gold mine stands out to be a challenge to anti-child labour actors in their efforts to control and reduce child labour.

\section{Motivation and Incentives}

Results from interviews and focus group discussions with study participants showed that lack of motivation and incentives for anti-child labour actors responsible for stopping child labour is a significant challenge. The participants observed that, most local government anti-child labour actors lack motivation and incentives that would raise their morale for performing their duties effectively. For example, most local government anti-child labour actors in the study area were working under resource constraints, limited budgets, inadequate staff, lack of transport means to enable them visit and conduct inspections in remote gold mining areas. This type of working environment tends to demotivate anti-child labour actors leading to passive participation and performance of their child labour control and prevention duties.

However, the literature survey shows that there is an increase in work performance if employees receive incentives and motivation compared with those employees who do not receive any kind of incentives and motivation for performing similar work (Condly, Clark, and Stolovitch, 2003). Such observation signifies the important role played by incentives and motivation offered to workers in order to enhance and maximize their job performance. The works of two psychologists; Abraham Maslow (1943) and Frederick Herzberg (1959) are very significant for employee motivation purposes. Maslow argued that, employees are motivates to satisfy five basic need levels: physiological needs, security needs, belongingness needs, self-esteem and self-actualization. These needs may generally be satisfied by adequate wage or salary and attractive incentive packages. Likewise Hertzberg asserted that, employee job satisfaction and dissatisfaction are driven by factors such as motivation and hygiene. He added that employees' motivation is instrumental to the willingness to perform optimally and the commitment to work is proportional to employee's satisfaction which is reflected through achievement in work, recognition, promotion opportunities and so on. Thus, provision of incentives and motivation becomes an essential drive that inspires an individual employee to attain personal and company goals. These motivating factors are considered to be fundamental to anti-child labour actors' involvement in child labour elimination in small-scale gold mining sites. Demotivated antichild labour actors do not take active actions to control child labour and becomes another challenge.

\section{CONCLUSION AND RECOMMENDATIONS}

The study has identified seven different factors producing challenges to actors responsible for control of child labour in small-scale gold mining sites. The challenges arise from the households' supply side and community contexts. For successful eradication of child labour in small-scale gold mining communities, the study recommends the following policy intervention actions: the government authorities through the Ministry of Energy and Minerals and other relevant ministries should regularly conduct awareness-raising and outreach sessions at village and ward levels on the hazards of child labor in small-scale gold mining as well as other economic sectors where child labour is dominant. Mining officers should also conduct training to small-scale gold miners on modern mining techniques that are not labour intensive to avoid the use of children's labour force. The government should empower village and district child labour committees, most vulnerable children committees and local community leaders through 
a process of leadership development, organizational capacity building, education, and consciousness raising so that they may be able to actively participate in the process of eliminating the challenges facing actors responsible for control of child labour. The government education officials at ward and district levels should conduct awareness raising sessions to parents at community level on the importance and benefits of schooling and educating children.

\section{Acknowledgements}

I extend my profound gratitude to the University of Dar es Salaam management, and government authorities at regional and district levels for granting me the permission to conduct this research in the targeted area. I am so thankful to Prof. Elliott P. Niboye for providing supervision and guideline for conducting this study. I also acknowledge the cooperation I received from all anonymous respondents at regional level in Shinyanga as well as those in Kahama district. The contribution of other individuals and officials concerned with child labour eradication at national level is also acknowledged.

\section{Conflict of Interest Statement}

The author declare no potential conflicts of interest with respect to the research, authorship, and/or publication of this article.

\section{Funding}

The researcher has not received any financial support for the research, authorship, and /or publication of this paper.

\section{References}

AMCA Inter-consult LTD. (2012). Study of migration of youth in mining areas in Tanzania: Geita Gold Mines, Shinyanga Diamond Mines, Kahama Gold Mines. Retrieved from https://assets.terredeshommesschweiz.ch/downloads/migration_study_of_youth_in_mi ning areas_in tanzania_by terre des_hommes_schweiz.pdf

Andvig, J. C. (2000). An Essay on Child Labour in Sub-Saharan Africa: A Bargaining Approach. Oslo, Norsk Utenrikspolitisk Institutt. Retrieved from https://www.researchgate.net/publication/266406404_An_Essay_on_Child_Labour_in Sub-Saharan_Africa-A_Bargaining_Approach/download

Baregu, K. M. (2011). Situation Analysis on Child Labor in Tanzania Mainland and Zanzibar. Supported by the US Department of Labour, Retrieved from https://www.dol.gov/ilab/reports/pdf/TanzaniaSA2011.pdf

Becker, K. F (2004). The Informal Economy. Stockholm: SIDA Publications.

Bento, A. L. (2017). All That is Gold Does Not Glitter: Mercury Exposure to Children in Artisanal and Small-scale Gold Mines and the Inadequacy of the Minamata Convention. Journal of International Business and Law, 16(2), 10. Available at: http://scholarlycommons.law.hofstra.edu/jibl/vol16/iss2/10

Brandt, K., Rutasitara, L., Selejio, O., \& Trifkovic, N. (2017). Entrepreneurship and human capital development in children. UNU- WIDER Working Paper, 198. Retrieved from https://www.wider.unu.edu/sites/default/files/Publications/Workingpaper/PDF/wp2017- 198.pdf

Cheetham, N. (2002). Community participation: What is it? Transitions, 14(3), 4. 
Condly, S. J., Clark, R. E., \& Stolovitch, H. D. (2003). The Effects of Incentives on Workplace Performance: A Meta-analytic Review of Research Studies. Performance Improvement Quarterly, 16(3), 46-63.

Dachi, H.A., \& Garrett, R.M. (2002).Child Labour and its Impact on Children's Access to and Participation in Primary Education: A case study from Tanzania. Retrieved from http://ageconsearch.umn.edu/bitstream/12848/1/er030048.pdf

Diaz, P. (2000). Definitions of Community. Retrieved from http://uregina.ca/ sauchyn/socialcohesion/definitions\%20of\%20community.htm

Härkönen, J., Bernardi, F., \& Boertien, D. (2017). Family Dynamics and Child Outcomes: An Overview of Research and Open Questions. European Journal of Population. DOI:10.1007/s10680-017-9424-6

Henckel, J., Poulsen, K.H., Sharp, T., \& Spora, P. (2016). Lake Victoria Goldfields. Episodes, 39(2), 135-154. DOI: 10.18814/epiiugs/2016/v39i2/95772

Herzberg, F. (1959). The motivation to work. New York, Wiley

Huebner, B. (2011). Genuinely collective emotions. European Journal for the Philosophy of Science, 1, 89-118

Human Rights Watch. (2013). Toxic Toil: Child Labour and Mercury Exposure in Tanzania's Small-Scale Gold Mines, Retrieved from http://www.hrw.org

ILO. (2016). Tanzania national child labour survey 2014: Analytical Report. Geneva: ILO. Retrieved-from:

http://www.ilo.org/ipec/Informationresources/WCMS_IPEC PUB 28475/langen/index.htm

ILO. (2019). Tackling child labour: 100 years of action / International Labour Organisation, Fundamental Principles and Rights at Work Branch (FUNDAMENTALS). International Labour Office, CH-1211 Geneva 22, Switzerland

ILO-IPEC. (2004). Action against Child Labour in Small-Scale Mining \& Quarrying. A Thematic Evaluation. International Labour Office, CH-1211 Geneva 22, Switzerland

ILO \& UCW. (2010). Joining forces against child labour. Inter-agency report for The Hague Global Child Labour Conference of 2010 / Understanding Children's Work (UCW) Programme -International Labour Office, Geneva

Kalwani, J. D., \& Fumbuka, C. (2014). Impact of Mercury Use in Artisanal Gold Mining on Community Health: Kahama Case Study, Tanzania. The African Resources Development Journal, 1(1), 23-38

Lahiri-Dutt, K. (2018). Extractive peasants: reframing informal artisanal and small-scale mining debates. Third World Quarterly, 39(8), 1561-1582

Maslow, A. H. (1943). A theory of human motivation. Psychological Review, 50(4), 370- 396. DOI: $10.1037 / \mathrm{h} 0054346$

Metta, E., Ramadhani, A., \& Geubbels. E. (2017). Pathways and Experiences of Children and Adolescents Who Engage in Artisanal and Small-Scale Gold Mining-Related Activities in Tanzania. Dar es Salaam, Tanzania: Pact and Ifakara Health Institute

Merket, H. (2018). Mapping artisanal and small-scale mining in northwest Tanzania A survey on its nature, scope and impact. International Peace Information Service vzw -IPIS, Mwanza, Tanzania, Retrieved from https://ipisresearch.be/wpcontent/uploads/2019/10/1910-DGD-Tanzania-final-Report-WEB2.pdf 
Mollel, H. A. (2010). Participation for local development: The reality of decentralisation in Tanzania. Groningen: s.n. Retrieved from https://www.rug.nl/research/portal/files/14672724/03c3.pdf

Mutagwaba, W., Tindyebwa, J. B., Makanta, V., Kaballega, D., \& Maeda, G. (2018). Artisanal and small-scale mining in Tanzania - Evidence to inform an 'action dialogue'. Research report, IIED, London

O'Driscoll, D. (2017). Overview of child labour in the artisanal and small-scale mining sector in Asia and Africa. K4D Helpdesk Report. Brighton, UK: Institute of Development Studies

Page, N., \& Czuba, C. (1999). Empowerment: What is It? Journal of Extension, 37(5), 1-6.

Reysen, S., \& Branscombe, N. R. (2008). Belief in collective emotions as conforming to the group. Social Influence, 3, 171-188

Rodrigue, J., Comtois, C., \& Slack, B. (2006). The Geography of Transport Systems. New York.

Rowlands, J. (1997). Questioning Empowerment: Working with Women in Honduras. Oxford, UK: Oxfam

SOS Children's Villages International. (2014). Assessment Report of the Alternative Care System for Children in Tanzania. A-6010 Innsbruck, Austria Retrieved from https://www.sos-childrensvillages.org/getmedia/2f9b94e6-5630-43c3-bb7c658cc287ee81/FF2014-WEB-5_1.pdf

Sullivan, G. B. (2013). Collective pride, happiness, and celebratory emotions: aggregative, network, and cultural models. Retrieved from https://core.ac.uk/download/pdf/228143451.pdf

Understanding Children's Work [UCW]. (2017). Child labour and the youth decent work deficit in Tanzania. Retrieved from http://www.ucwproject.org/attachment/3009201844child_labour_youth_employment Tanzania.pdf

UNICEF. (2005). State of the World's Children 2004: Childhood Under Threat. New York, Retrieved from https://www.unicef.org/publications/files/Child_Protection_Information_Sheets.pdf

United Republic of Tanzania/NBS. (2016). Shinyanga Region: Basic Demographic and SocioEconomic Profile 2012 Population and Housing Census. Dar es Salaam, Tanzania

USDOL. (2018). Tanzania 2018 Findings on the Worst Forms of Child Labor. Retrieved from http://www.dol.gov/ilab/reports/child-labor/tanzania.htm

Zadeh, B.S., \& Ahmad, N. (2010). Participation and Community Development. Current Research Journal of Social Sciences, 2(1), 13-14. 